\title{
ADOPTING ENGLISH AS A MEDIUM OF INSTRUCTION (EMI) IN BRAZIL AND FLANDERS (BELGIUM): A COMPARATIVE STUDY
}

\author{
Felipe Furtado Guimarães ${ }^{1^{*}}$ \\ ${ }^{1}$ Universidade Federal do Espirito Santo, Vitória, ES, Brasil \\ Marcelo Martins Kremer ${ }^{2 * *}$ \\ ${ }^{2}$ Ghent University, Ghent, Belgium
}

\begin{abstract}
The objective of this study is to discuss the adoption of English as a Medium of Instruction (EMI) in the Brazilian and Flemish contexts, considering the influence of globalization and internationalization on the languages in higher education. To reach this goal, a bibliographic research ${ }^{1}$ was carried out, in order to analyze documents related to language teaching/learning, including books, journals, government documents, official websites and reports from international organizations. Data from these sources were categorized according to the country of origin and EMI approaches. Recurring themes were identified using different genres of documents, in order to establish connections between official documents (such as legal ones) and practices described in research published in journal articles and book chapters, looking for connections between theory and practice. Information collected comprised the data retrieved in Brazil and in Flanders, used to generate discussions around challenges and opportunities for adopting EMI in these contexts. The study concludes that actions such as the creation of local support units (for languages) at universities are necessary to overcome the challenges identified in the preparation and implementation of EMI courses in those contexts.

Keywords: EMI; Internationalization; Higher Education; Brazil; Flanders
\end{abstract}

\footnotetext{
" PhD candidate in the graduate programs of Linguistics (PPGEL) at the Federal University of Espirito Santo (UFES/Brazil) and Humanistic Studies \& Languages (DHH) at the Pablo de Olavide University (UPO/Spain). His current research topics include language policies, internationalization, intercultural communication and multilingualism for higher education. He also holds a master's degree in Public Management (PPG-GP/UFES) and he is currently working as a translator-interpreter at the Division for Languages, in the International Office of UFES, developing joint research with UPO. E-mail: felipeguim@hotmail.com. ORCID: https://orcid. org/0000-0001-6184-3691.

${ }^{* *}$ Licentiate of letters (English) from Universidade Federal de Santa Catarina (UFSC). Has a master's degree from the same university at the Graduate Program in Letters - English and Correspondent Literature. At the present moment, as a PhD Researcher at Ghent University (Belgium), his main focus is on the use of English as a medium of instruction in higher education in contexts in which English is not a native language. E-mail: marcelomkremer@gmail.com. ORCID: https://orcid.org/0000-0001-8301-8692.
} 


\section{Introduction and initial considerations}

Globalization, with its increasing impacts on the flows of people, information and goods, has effects on all areas of civil life, including the educational sector, mainly through the process of internationalization of higher education (IHE). Although globalization and internationalization are different phenomena, they are somehow intertwined, insomuch as "internationalization is changing the world of education and globalization is changing the world of internationalization" (Knight, 2003:3). Internationalization changes the world of education by affecting student mobility (e.g. Wang et al., 2014) and curriculum (Leask, 2015), for example. Globalization changes the world of internationalization by changing migration flows related to better opportunities in education (e.g. Da Câmara, 2014; Camargo \& Hermany, 2018), for example.

In regions such as North America and Europe, commercial and marketrelated aspects, such as the generation of income and financial incentives connected to fees paid by international students, motivate the competition for better positions in global rankings expressed in higher indices of IHE (Kubota, 2009; Finardi \& Rojo, 2015; Baumvol \& Sarmento, 2016; Finardi \& Guimarães, 2017) resulting in a process of "commodification" of education.

In the European context, the Bologna Process (BP) was created to "increase the international competitiveness of the European system of higher education [...] ensuring that the European higher education system acquires a world-wide degree of attraction" (Bologna Declaration, 1999). In 2019 Europe celebrates the $20^{\text {th }}$ anniversary of the $\mathrm{BP}$ which is based on "international cooperation and academic exchange that is attractive for European students and staff as well as to students and staff from other parts of the world" (Bologna Process). ${ }^{2}$ However, some studies suggest that the underlying motivation of the BP was to make European higher education institutions (HEIs) more competitive, especially in relation to the ones in the USA (e.g. Ljosland, 2015; Albuquerque et al., 2019).

In fact, Moore and Finardi (2019) state that European higher education was transformed by the Bologna Process, aimed to foster international attractiveness and competitiveness through a transferable system of credits to foster academic mobility ${ }^{3}$ and to ensure comparability in the standards and quality of higher education qualifications. The importance and impacts of the Bologna Process are also discussed by Bianchetti and Magalhães (2015) and Albuquerque et al. (2019) who claim that BP also changed the autonomy of HEIs, by interfering in the decisions of administrators and managers, and changing the use of languages in the higher education context.

Considering the impact of the Bologna Process in the European IHE, Flanders belongs to a scenario composed of a European level and a local level. Regarding the first, after the BP, European countries have agreed to the European Policy Cooperation (ET2020) framework that set strategic objectives, making mobility a reality. It links the attractiveness of European higher education set by the BP with mobility. On the one hand, mobility presents opportunities for 
cooperation and mutual trust; attractiveness, on the other hand, is related to economic rationales and competition between higher education institutions ( $\mathrm{Sin}$, Veiga, \& Amaral, 2016). At a local level, the Flemish Parliament set a policy in 2010 for higher education, ${ }^{4}$ in terms of internationalization. It sets as a goal that Flemish professors and students must be able to communicate and exchange with the international academic community. Also, it establishes that Flemish higher education must be open to students and professors from abroad.

In Brazil, however, IHE happens in a different way, since the public system of higher education (as well as elementary and high school education) is free of charge for Brazilian and international students, thus charging no tuition fees, as discussed by Ramos (2018), although most Brazilian university students attend private colleges. This system comprises federal universities (undergraduate programs, master's and doctoral degrees) and also federal institutes of education, science and technology (which also offer high school and vocational education, as well as higher education). At the graduatelevel, research is funded by governmental agencies such as CAPES ${ }^{5}$ and $\mathrm{CNPq}^{6}$. That being said, the Brazilian system may not be motivated towards internationalization as a solution to finance higher education in the form of attraction of international students and fees. As such, the Brazilian IHE allows different alternatives to finance higher education and possibilities for more balanced relations and networks among various countries and academic interests. However, IHE in Brazil is a very recent and incipient process (e.g. Lima \& Maranhão, 2009; Miranda \& Stallivieri, 2017), propelled mainly by government-funded initiatives such as the Science without Borders $(\mathrm{SwB})^{7}$ program (no longer active), Languages without Borders $(\mathrm{LwB})^{8}$ program, and the Capes PrInt ${ }^{9}$ program. (e.g. Guimarães \& Finardi, 2019). However, one should note that international cooperation in Brazilian education exists for at least 50 years, as in the case of PEC-G and PEC-PG programs (e.g. Bizon, 2013) and it has been intensified by programs such as SwB and LwB.

\subsection{Internationalization and Mobility}

Though internationalization is not limited to academic mobility, many of its activities are still focused on mobility. The Science Report 2015 published by UNESCO, the United Nations Educational, Scientific and Cultural Organization, shows the long-term growth of tertiary-level international students worldwide. ${ }^{10}$ While in 1975 there were 0,8 million students in academic mobility, in 2013 there were 4,1 million international students worldwide. More recent data from the International Organization for Migration (IOM), another organization related to the United Nations (UN), available through the Global Migration Indicators $(\mathrm{GMI})^{11} 2018$, show that the number of international students increased to 4,8 million. According to Dowle (2016), the increasing flows of students can promote mutual understanding, increase knowledge and help in the building of lasting ties between countries. 
Data available at the website ${ }^{12}$ of the Organization for Economic Cooperation and Development (OECD) indicate that the top 10 countries/regions with the highest number of enrolled higher education international students ${ }^{13}$ were the following in 2016: 1) Luxembourg; 2) New Zealand; 3) United Kingdom; 4) Switzerland; 5) Australia; 6) Austria; 7) Belgium; 8) Canada; 9) Czech Republic; 10) Denmark. One can see that the majority of international students look for Europe as the main destination for higher education.

UNESCO indicates that the top 10 preferred destinations of international doctoral students (in science and engineering fields) ${ }^{14}$ in 2012 were: 1 ) the USA;2) the UK; 3) France; 4) Australia; 5) Canada; 6) Germany; 7) Switzerland; 8) Japan; 9) Malaysia; 10) Sweden. Once again, data from OECD and UNESCO indicate a mobility towards hegemonic countries. ${ }^{15}$ Besides, the outbound mobility ratio ${ }^{16}$ among doctoral students in 2013 is described in the following table, suggesting (except for Western Europe) that students from developing countries/regions are the ones who seek most education abroad:

Table 1. Outbound mobility ratio among doctoral students, by region of origin.

\begin{tabular}{|l|l|}
\hline Region of Origin & Percentage \\
\hline Central Asia & $7,6 \%$ \\
\hline Sub-Saharan Africa & $4,0 \%$ \\
\hline Arab States & $3,6 \%$ \\
\hline Western Europe & $3,3 \%$ \\
\hline Central and Eastern Europe & $2,0 \%$ \\
\hline East Asia and Pacific & $1,9 \%$ \\
\hline South and West Asia & $1,0 \%$ \\
\hline Latin America and Caribbean & $0,9 \%$ \\
\hline North America & $0,5 \%$ \\
\hline
\end{tabular}

Source: Authors, based on information available at the UNESCO website ${ }^{17}$.

Concerning mobility in Belgium, data from the Organisation for Economic Co-operation and Development (OECD) ${ }^{18}$ in 2017 show that $8,7 \%$ of all students enrolled in Belgian universities came from other countries - for instance, Flanders has around 120,000 students, according to the Statista ${ }^{19}$ website with data from 2018-2019, resulting in a population of over 10,000 international students. In addition, according to the Eurydice ${ }^{20}$ website (part of the European Commission) there are several programs to support international student mobility in Belgium, specifically at the Flemish community, such as: Erasmus Belgica; Cooperation with France; Washington Center for Internships; ASEM-DUO; Prince Philippe Fund; NARIC-Flanders; EuroPass; BENELUX Intergovernmental cooperation; Automatic recognition of higher education qualifications, through the Accreditation Organisation of the Netherlands and Flanders (NVAO); Joint and Double Degrees.

On a European level, Belgian is part of the European Policy Cooperation, which created in 2009 the 'ET 2020 framework', defined as "a forum which 
allows Member States to exchange best practices and to learn from each other" (European Commission). ${ }^{21}$ The ET 2020 framework aimed at promoting mobility, setting the goal of having at least $20 \%$ of higher education graduates having spent some time in academic mobility, either studying or training by 2020. As a response, the Flemish Government released a local supplementary document to the European policies named 'Brains on the move. Action plan for mobility 2013. The main objective of this action plan is to "allow students to acquire international and intercultural competences through high-quality mobility" (Departement Onderwijs en Vorming) ${ }^{22}$ and it proposed to achieve the European goal of $20 \%$ and push it forward, setting the goal of $33 \%$ of international mobility of all graduates by 2020 .

More recently, in March 2019, the Flemish Government released a monitoring report ${ }^{23}$ for its 2013 action plan evaluating its current status of development, by bringing updated figures concerning mobility. It pointed that, at the moment of its publication, $13.81 \%{ }^{24}$ of higher education diplomas are considered mobile, which is below the 20\% European objective and well below the 30\% Flemish objective set in 2013. The report did not venture in explaining the results, as its objective was to inform the reader about the ongoing development, and it did not explore (in depth) possibilities to change the subpar results. It merely stated that further steps are needed for promoting and supporting student mobility and improving its monitoring.

Existing imbalanced relations between developed and developing countries show that regions such as the UK, the USA, Australia and Canada receive the greatest share of international students (Lima \& Maranhão, 2009). Other countries, as in the case of Brazil, send ${ }^{25}$ more academics abroad (Brazil was placed $16^{\text {th }}$, with around 52,000 students sent abroad, in a 2017 report from UNESCO ${ }^{26}$, among $240+$ countries) than receive ${ }^{27}$ them, (around 490 students), according to a 2017 report from the Brazilian Ministry of Foreign Affairs ${ }^{28}$ (MRE).

Also, most of the international students coming to Brazil are from Africa and Latin America/Caribbean. However, data from international students in Brazil is often unreliable as can be seen in the British Council and FAUBAI (Brazilian Association of International Education $)^{29}$ report indicating that Brazil had more than 9,000 international students in 2016.

An important example of this mobility trend in Brazil was the Science without Borders (SwB) program, which ran between 2011-2016, funded by the Brazilian government. Considered the largest investment for IHE in Brazil (Finardi \& Archanjo, 2018), it sent more than 100,000 Brazilian academics abroad (from STEM ${ }^{30}$ areas), mainly to hegemonic countries, although few of the SwB scholarships offered to attract international students (interested in studying in Brazil) were used.

In this scenario, it is relevant to think about the concept of Internationalization at Home ( $\mathrm{IaH})$ as an interesting alternative for IHE, especially considering the importance of academic mobility for IHE and the decreasing funding for international mobility (Altbach \& Knight, 2007; Knobel, 2012; Manços \& 
Coelho, 2017). IaH has been defined by Beelen and Jones (2015:69) as "the purposeful integration of international and intercultural dimensions into the formal and informal curriculum [...] within domestic learning environments". In the Brazilian climate of "government cost-cutting and austerity" (Martinez, 2016:221) that has discontinued internationalization programs such as the SwB and $\mathrm{LwB}, \mathrm{IaH}$ can be used to promote international and intercultural activities locally (supported by foreign languages), without the need of costly investments in academic mobility.

\subsection{Internationalization and Languages}

Foreign languages (FL) play a key role in the development of IaH as means for students and staff to have access to international activities within local environments, when opportunities for going abroad become increasingly scarce in developing countries. FL can be used for delivering contents in a language other than the native language (L1). Also, academics who master FL can have access to materials produced in international networks of research and exchange experiences within such networks. Because of the centrality of language to education (Spolsky, 2004) and we add, especially in the context of IHE, there has been great discussion around the choice of the language(s) as the medium of instruction.

Concerning the English language, it can be seen both as the consequence and the main language medium of the globalizing processes, since it has become a lingua franca "on such a scale worldwide partly in response to globalization; but also, large-scale globalization is in part incumbent on the emergence of a globally diffuse lingua franca" (Jenkins, Cogo \& Dewey, 2011:303; and Jenkins, 2014).

The spread of English started after the Second World War and it is today "in a stronger position in the world not just than any contemporary language but also than any other historical language" (Spolsky, 2004:76). Spolsky (2004) also indicates the causes for this spread, which include (but are not limited to): a) the spread by military conquest; b) the fact that it became the language of administration in various places; c) its role as a lingua franca in multilingual settings; d) the idea that knowledge of English brought material advantages to those who learned it; e) the fact that it spread through urbanization and industrialization; f) it aided the process of education, religion and political affiliation in various places.

Within this scenario, pro-globalization perspectives see English with a progressive view (as discussed by Liu, 2019; Relaño-Pastor, 2015), while antiglobalization perspectives see English as a threat to local and indigenous languages (as discussed by Finardi, 2019). Pro-globalization perspectives, for instance, are being supported by governmental decisions, as in the case of Brazilian Law ${ }^{31} \mathrm{n}$. 13.415/2017. Just as globalization is seen to threaten local environments, using English can perpetuate inequalities and expand the unevenness of development, in ways that are not reversible (Finardi, 2016). A third perspective, a somewhat more progressive one, focuses on human agency and its transformationalist 
character (Moore and Finardi, 2019) to understand/explain the role of English in countries where it is not the first language. In this perspective, people in these countries use English and adapt it to local uses and needs, without importing the ideologies and cultures which come associated with English teaching and learning. This view is adopted by the authors of the present study.

In order to expand this discussion, Finardi (2016) indicates that English can be used to: a) maintain national cohesion; b) promote access to information and education; c) foster the social inclusion of diversity; d) fight against the commodification of education; e) encourage the circulation of academic production and scientific information; f) support the internationalization of education.

Concerning (a), English can be used to try to maintain the national cohesion in countries where multiple languages are spoken (e.g. Finardi \& Csillagh, 2016). In relation to (b), English can promote access to information and education with the use of Massive Open Online Courses [MOOCs] (e.g. Machado, 2019). Concerning (c), English could be used to foster the social inclusion of diversity in multilingual and multicultural contexts, as discussed by Vertovec (2007). In relation to (d), English could be used to fight against the commodification of education, if its users choose to appropriate the use of such language according to local needs (e.g. Relaño-Pastor, 2015). Concerning (e), English can encourage the circulation of academic production and scientific information with the creation of digital databases of studies in that language, when it is used as an academic lingua franca (Finardi \& França, 2016). Regarding (f), it can support internationalization in various forms, as discussed by Guimarães, Finardi and Casotti (2019).

In Brazil, explicit governmental guidelines for promoting the learning/ teaching of the English language can be found in Law n. 13.415/2017 (in a series of reforms in the National Guidelines for Education - LDB, in Portuguese), ${ }^{32}$ which indicated that English is the only mandatory foreign language to be taught in elementary education, from the $6^{\text {th }}$ grade on. Though there is no explicit language policy in higher education, the role of English is also highlighted in internationalization programs such as SwB, LwB and Capes Print.

In Flanders, at least two foreign languages are studied in schools, namely French (the official language of the Southern region of the country), English or German. According to the most recent data available (Eurostat, 201933) in 2017, $99.8 \%$ of Flemish pupils in secondary education studied two languages or more. Moreover, CLIL (Content and Language Integrated Learning) is also allowed under Flemish regulations - up to $20 \%$ of the teaching time can be taught in English, French or German. Looking at the offer in $2019^{34}$ one can see that most CLIL offer is for English with 99 schools, French comes second with 69 and German with $6 .{ }^{35}$

In 2013, the Flemish Government presented a 'Master plan to reform secondary education, ${ }^{36}$ concerning the role of foreign languages. It stated that knowledge of modern foreign languages is essential for young people's career opportunities and the development of the Flemish economy in a globalized world (our translation). In the same document, they refer to the pupils' knowledge of 
French as being below the expected, making no mention of English. One can suppose they might be satisfied with the English level shown by students.

Regarding the general population, Flanders scores favorably in terms of English proficiency, according to the English Proficiency Index (EPI) developed by English First (EF) ${ }^{37}$ Belgium is placed $13^{\text {th }}$ among 100 countries listed, ranked as a "very high proficiency" country. Considering Flanders only, the results are even better as it would be placed $8^{\text {th. } .38}$

\subsection{English as a Medium of Instruction}

Studies in the field of Education and Linguistics use various terms to describe approaches for language teaching/learning of a given content through a foreign language, such as Content and Language Integrated Learning (CLIL), Integrated Content Learning (ICL), Content Based Learning (CBL), Language Across the Curriculum (LAC), Integrating Content and Language in Higher Education (ICLHE), and English as a Medium of Instruction (EMI), to name but a few. They vary on how they accommodate the balance between the focus on the teaching/learning of content and language. While approaches such as CLIL and ICLHE have a dual focus and provide equal importance to content and language learning, EMI is more associated with the teaching of contents through English without an explicit language learning aim (Schmidt-Unterberger, 2018).

Dalton-Puffer (2012:102) states that labels such as CLIL, ICLHE or EMI cover "a wide range of implementation types from fully English-medium programmes to curricula with a small number of English-medium subjects". Besides, decision makers in the educational area are sometimes unclear about the aims pursued by the various types of implementation for these approaches. Moreover, Baumvol and Sarmento (2016) indicate that such labels do not have precise criteria for distinguishing them and they are sometimes mistakenly used interchangeably.

An increasing number of higher education institutions in non-Anglophone countries opted to offer courses in English, in order to broaden their international appeal to attract students/researchers from various backgrounds to their campuses (Dowle, 2016; Moore \& Finardi, 2019). Teaching of university contents through English is not a new phenomenon, but in recent years its growth has increased to the point of being known as an "unstoppable train" (Macaro, 2015:7). Between 2002 and 2014, Europe alone experienced a growth rate of almost 1,000\% in EMI courses, with around 8,000 programs (Wächter \& Maiworm, 2014) available in EMI.

Martinez (2016) indicates that the earliest examples of EMI have their roots in colonization or direct foreign influence, as in the case of Japan (Sophia University of Tokyo, in 1913), China (University of Hong Kong, in 1911) and the Philippines (Central Philippine University, in 1905). In recent times, the incentive for creating EMI comes from higher education institutions, like the Maastricht University (MU) in the Netherlands, one of the first higher education institutions (HEIs) in Europe to offer a degree program entirely in English, starting in the mid-1980s. 
Motivated by the Maastricht Treaty (1992), the Bologna Process (1999) and an "Europeanization" movement, EMI courses increasingly became an integral part of the curriculum across the Maastricht University (Wilkinson, 2013), in line with the fact that English is the most widely learned foreign language in schools across the European Union and the most widely known language in Europe (European Commission, 2006; Cucchi, 2019).

Although the adoption of EMI in Europe is an increasing phenomenon (Macaro, 2015), this process may vary among European countries. In countries where the native language is considered a "prestigious" language, such as Germany, France and Spain, the adoption of EMI can be considered "slower" than in countries where native languages are not as prestigious (and widespread) as German, French and Spanish - as in the case of Norway, Sweden, Finland, Denmark, Belgium, the Netherlands and Turkey (e.g. Lindström, 2012; Ljosland, 2015; Garson, 2016; Taquini, Finardi \& Amorim, 2017). This increasing adoption of EMI may be motivated by the fact that higher education institutions wish to become more attractive for international students (e.g. Guimarães, Finardi \& Casotti, 2019; Finardi \& Rojo, 2015), in order to expand their revenue.

In the case of EMI (an approach for languages used in instruction, discussed by Dearden, 2014; Doiz, Lasagabaster \& Sierra, 2013; Lanvers \& Hultgren, 2018), which clearly indicates the use of English as the language of instruction, it has been increasingly used in higher education contexts, since the establishment of the Bologna Process (BP) - an attempt to harmonize Higher Education in Europe. One can also see the BP as an attempt to make Europe a more competitive and socially sustainable region, where knowledge and languages play a key role (Bianchetti \& Magalhães, 2015) for attracting students, in order to cope with the expansion of international higher education in English speaking countries, as in the case of the USA.

Macaro and others (2018) published a systematic review of EMI cases in higher education concluding that current EMI implementations produce more challenges than opportunities for higher education. When discussing the future of EMI, these authors suggest that policy makers and university managers may overcome the sociolinguistic and sociocultural objections, in order to expand EMI in the higher education area. Leffa (2013) discusses examples of such objections, as in the case of countries where English is rejected because it is associated with linguistic imperialism. For this to be overcome, English may be appropriated by its users, so that they use the language according to local needs, especially in higher education contexts. However, without adequate planning, higher education institutions "may actually be damaged by the introduction or development of EMI" (Macaro et al., 2018:68) - adequate planning includes the assessment of the local needs of institutions and of the options available for EMI implementation, that is, not using solutions directly imported from abroad, without the necessary adjustment. Therefore, systematic reforms for teacher preparation/resourcing are necessary both before and during the implementation of EMI initiatives.

Coleman (2006) discusses the global debates around the use of English as an international lingua franca, with the adoption of EMI in higher education as an 
increasing concern, against the backdrop of plurilingual and multilingual policies in the European Union and the Council of Europe. He indicates that globalization and marketization play important roles in the "inexorable increase in the use of English" (Coleman, 2006:1), posing a challenge for the diverse European scenario of languages. Therefore, alternatives for promoting multilingualism have been discussed in various contexts, such as the Intercomprehension Approach - IA (e.g. Guimarães \& Finardi, 2018; Araújo e Sá \& Simões, 2015; Martins, 2014; Meissner, 2010).

According to Dalton-Puffer, (2012), there are many motivations to use EMI, among which are strategic motivations, related to planning and actions used by universities to attract international students and staff, as well as a bid for membership among "elite" institutions. This type of motivation is also mentioned by Baumvol and Sarmento (2016). Pedagogical motivations are related to preparing students for the international job-market or global academic life. Substantial motivations are related to the increasing use of English for communicating research in the scientific community.

Similar motivations for adopting EMI are: a) attracting students from other countries; b) preparing students for mobility and a globalized labor market; c) raising the profile and ranking position of the university - as discussed by Wächter and Maiworm (2014) and Martinez (2016).

Although EMI implementation is no longer the result of direct colonization (as it occurred in Japan, China and the Philippines in the past), one can see the influence of neo-colonial forces (Kumaravadivelu, 2003) in the adoption of English (and not other languages) as the medium of instruction, so much so that the term EMI is known in the context of higher education and not another possible acronym such as SPAMI (Spanish as a Medium of Instruction) for example. As indicated by Martinez (2016:195), in the case of the Maastricht University (the Netherlands), the founders of the EMI program aimed to "prepare students for an increasingly globalized business world profoundly influenced by American commercial interests". Although the situation might seem a little different in Spain, in other non-Anglophone countries (such as the ones in Scandinavia), local languages are apparently considered insufficient to keep students (or the university itself) competitive in a world where English has so much influence and power.

Considering the challenges and opportunities related to EMI (which will be discussed further on), this study aims to discuss the EMI scenario in Flanders (Belgium) and in Brazil, in order to discuss possibilities for the implementation and development of EMI in these contexts. The reasons for choosing these two contexts (Flanders and Brazil) are because such countries are in different stages of EMI implementation, so that a comparison can be made for checking different approaches for EMI, taking into account the challenges and opportunities associated with English-Medium Instruction. On the one hand, Flanders has more experience (and faces various challenges) with EMI adoption because of the early implementation of this approach in the European context. On the other 
hand, Brazil is in the early stages of EMI implementation and can learn from other countries, as well as find alternatives for the challenges in the adoption of EMI. In addition, each of the authors of this study is familiarized with one of the specific contexts discussed in this study, so that a comparison of such contexts can result in interesting suggestions for EMI implementation.

Within a panorama of rapid expansion of internationalization of higher education and academic mobility, the motivation for this study is based on the different levels of development of EMI in Brazil and Belgium (as is discussed in sections 3 and 4 of this study) - while Brazil is in its early stages of EMI development (e.g. Baumvol \& Sarmento, 2016), Belgium has been discussing strategies for implementing EMI in higher education for some time (e.g. Martinez, 2016). The discussion of EMI in these two countries may suggest opposite views regarding the adoption of this approach. Therefore, the present study may contribute to informed decisions concerning EMI implementation.

\section{Materials and methods}

In order to reach the goal proposed in this study, a bibliographic review was carried out for gathering published materials in the form of books, journals, government documents, official websites and specialized documents (such as reports from international institutions) connected to internationalization and EMI. Databases from international organizations such as UNESCO and OECD were also consulted for information related to academic mobility, considering the periods covered by the data in such databases, and the recent literature in the field of internationalization and EMI. Data retrieved from these sources in Brazil and Flanders were then contrasted to generate discussions and conclusions, as well as presenting alternatives/suggestions for EMI implementation.

\section{Results}

\subsection{The situation of Brazil}

Brazil is the largest country in South America, the world's fifth-largest country by area and the fifth most populous. It is also the largest nation to have Portuguese as an official language (and the only one in the Americas), boosting great diversity due to the mixture of cultures that came to that country during colonization, slavery and more recently mass migration from various parts of

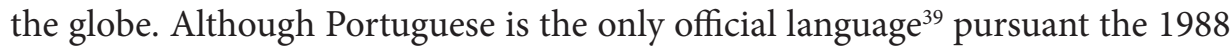
Federal Constitution, Brazil has more than 250 languages, including indigenous, heritage, sign, creole and African-Brazilian languages, according to the National Inventory of Linguistic Diversity (INDL, in Portuguese)..$^{40}$

As suggested elsewhere (e.g. Finardi, 2016), Brazilians should recognize and preserve their multilingualism by fighting against the omission/discrimination towards (linguistic) minorities and, at the same time, attempting to overcome 
ideological barriers to learn English as a global language (Leffa, 2013). In addition, Leffa (2013) warns Brazilians against linguistic isolation in a country where the only official language is Portuguese, and where people face various challenges to learn other languages, whether that is the language of their relatives (heritage languages), the language of neighbor countries (mainly Spanish) or the international language (English). In a country with few English speakers (around 5\%), ${ }^{41}$ adopting EMI can represent a great challenge for educational practices, language policies and management of financial resources. This percentage was confirmed in a piece of news ${ }^{42}$ of 2018 , indicating that Brazil is placed $41^{\text {st }}$ in a ranking of 70 countries, related to proficiency in English.

Studies about the adoption of EMI are quite recent in Brazil, as shown by Haus (2018), Verdu (2017), Baumvol and Sarmento (2016), Jordão (2016), and Martinez (2016). While some of these authors (e.g. Verdu, 2017) claim that English should be used as an academic lingua franca, others criticize the dominance of English over other languages in higher education (e.g. Lin, 2019; Moore \& Finardi, 2019). Concerning the studies mentioned above, Haus (2018) discusses the beliefs of EMI teachers, while Verdu (2017) indicates the importance of EMI adoption for internationalization at home, along with Baumvol and Sarmento (2016). Martinez (2016) indicates the challenges and opportunities for EMI adoption in Brazil, and Jordão (2016) discusses the use of English for internationalization.

Concerning reports about EMI in Brazil, an important document was jointly published by the British Council (BC) and the Brazilian Association of International Education (FAUBAI) in 2016, to identify and present the courses taught in English in Brazil across 4 regions (except for the North region), entitled "Guide of Brazilian Higher Education Courses in English". For this guide, 270 HEIs were contacted, 90 HEIs answered the survey, 45 of which claimed to offer EMI courses and activities. Concerning the type of courses offered in English, most of them were short-term courses (418), followed by undergraduate courses (197), graduate courses (44), graduate programs (8) and undergraduate programs (4).

The objective of that guide was to act as a reference document for international students and researchers who wished to study in Brazil, besides encouraging the internationalization of higher education in Brazil through the attraction of international academics to that country (Dowle, 2016). Moreover, the survey carried out for the guide identified 671 courses taught in EMI, suggesting that more and more Brazilian HEIs are keen to offer their expertise to a wider range of (mainly English-speaking) academics, propelling the internationalization process in Brazil.

The 2016 guide was followed by a 2018-2019 edition, entitled "Guide to English as a Medium of Instruction in Brazilian Higher Education Institutions". For this guide, 240 HEIs were contacted, 84 of which answered the survey and 66 of which informed that they offered EMI courses. A brief comparison between the two editions can be found in the following table. 
Table 2. Key findings in Brazil about EMI

\begin{tabular}{|l|l|l|}
\hline Aspect & 2016 & $2018-2019$ \\
\hline HEIs contacted & 270 & 240 \\
\hline Answered the survey & $\begin{array}{l}90 \\
(33 \% \text { of the contacted HEIs })\end{array}$ & $\begin{array}{l}84 \\
(35 \% \text { of the contacted HEIs })\end{array}$ \\
\hline $\begin{array}{l}\text { Number of HEIs that offered EMI } \\
\text { courses }\end{array}$ & $\begin{array}{l}45 \\
(50 \% \text { of the respondents })\end{array}$ & $\begin{array}{l}66 \\
(79 \% \text { of the respondents })\end{array}$ \\
\hline Public HEIs & $51.1 \%$ & $61 \%$ \\
\hline Private HEIs & $48.9 \%$ & $39 \%$ \\
\hline Number of international students & 9,884 & 17,326 \\
\hline Undergraduate programs & 4 & 1 \\
\hline Postgraduate programs & 8 & 5 \\
\hline Undergraduate courses & 197 & 235 \\
\hline Postgraduate courses & 44 & 406 \\
\hline Extracurricular courses & 418 & 274 \\
\hline Total number of EMI courses & 671 & 921 \\
\hline
\end{tabular}

Source: Adapted from Gimenez et al. (2018).

These findings suggest a significant increase in the number of EMI courses offered in Brazilian HEIs (921), and an increase in the number of public HEIs offering EMI courses, when compared to the 2016 report. The number of international students in Brazilian HEIs has also increased significantly. Undergraduate and postgraduate courses have also expanded their EMI offer for 2018-2019.

The percentage of participation of institutions in the questionnaire used in those guides was almost the same in the two editions, but the number of institutions offering EMI courses had an increase of 29\%. Postgraduate courses are still the main area in which EMI is adopted, maybe because changes in curriculum are more flexible at this level of education. Still in relation to the results in Table 2, one can see that public HEIs increased the offer of EMI, while private ones decreased - this could be the result of the financial and political crisis that has been affecting Brazil since 2016, and also the result of governmental decisions, as discussed by Finardi and Archanjo (2018).

\subsection{The situation of Flanders (Belgium)}

Belgium has two main linguistic groups, the Dutch-speaking (mostly Flemish Community - 59\% of the population or 6.5 million people) and the French-speaking Community ( $40 \%$ of the population or 3.5 million people). There is also a small German-speaking Community (1\% of the population), in the East Cantons. The region of Brussels-Capital is the only bilingual area in the country, although French has more presence in everyday life, and has a population of around 1.2 million people. The linguistic diversity in Belgium (and related political conflicts) has consequences such as the complex system of governance, 
made up of three levels: $a$ ) the federal government; $b$ ) the 3 language communities (Flemish Community, French Community and German-speaking Community); and c) the 3 regions (Flemish, Walloon and Brussels-Capital). More information about Belgium can be found in STATBEL, ${ }^{43}$ the Belgian Statistical Office. The word 'Flemish' might be used to refer to the variety of Dutch spoken in Flanders. Officially, though, Dutch is the language of the Flemish community, and we will adopt the official standard for the present article, and use 'Dutch' to refer to the language and 'Flemish' to refer to the community and its people.

Language is a sensitive issue particularly in Flanders. For historical reasons, French was the language of status and used by the upper classes and "the Dutch language has been constructed as a key marker of Flemish identity and as a strong emancipatory force for use against the dominance of French, which should be understood in a Belgian context from 1830s onwards" (van Splunder, 2014, p.239). After Latin fell into disuse in the Belgian context, French was the language of instruction in Flemish universities until Ghent University adopted Dutch as its official language in 1930, a hundred years after Belgium was established ${ }^{44}-$ this is in line with the discussions by Spolsky (2004) regarding the formation of nation-states and the languages chosen for them. Language regulations tended to be strict (and difficult to maintain), and in 1963, the Law Concerning Language Regulation in Education defined Dutch as the language of education in the Dutch-speaking language area, French in the French-speaking language area, and German in the German-speaking language area.

Later, in the 2003 Decree (Flemish law), Dutch is explicitly stated as the language of instruction in all Flemish universities and colleges allowing for only $10 \%$ of 'other languages' at bachelor level, and 'a certain degree' of other languages at master level. The 2012 Flemish Decree is more permissive and indicates, again, that Dutch is the language of instruction in all Flemish universities, and that another language can be used in exceptional cases, such as programs created specifically for foreign students besides linguistics and literature programs.

The law allows that a maximum of $18.22 \%$ of credits at bachelor level and $50 \%$ at master level can be taught in a language other than Dutch (van Splunder, 2014). Doctoral programs are not mentioned as they are considered employment positions in Flanders, and as such they can be effectively conducted $100 \%$ in a foreign language. In order to guarantee the quality of education, regulations also explicitly refer to language tests to anyone teaching a language other than their first language (L1) and require a C1 level according to the Common European Framework of Reference for Languages (CEFR). As a result, the Interuniversity Test of Academic English (ITACE) was created, a consortium of Flemish universities to provide standardized academic English proficiency tests for students and lecturers. ${ }^{45}$

Concerning the EMI offer in Flanders, data available at the Higher Education Register, which is the official website of the Flemish government dealing with higher education, ${ }^{46}$ list all programs available at undergraduate and graduate levels in Flanders in all of its 40 higher education institutions. For the sake of the present study, we use the offer for the 2019-2020 academic year as reference. 
Regarding undergraduate programs, professional bachelor's, academic bachelor's and advanced bachelor's programs were included in the analysis. The definitions of each of these kinds of bachelor's programs is beyond the scope of this study. Suffices to say that they are all tertiary education programs and, as such, subsequent to secondary education and part of higher education and that the main distinction among them refers to their objectives. While professional bachelor's provides competences related to the practice of profession, the academic bachelor's is academically oriented. Lastly, the advanced bachelor's are specialization programs offered to professional bachelor's degree holders. ${ }^{47}$ As mentioned above, doctoral programs are considered employment positions and, therefore, are not listed on the website and are not considered in the data presented below.

Table 3. Key findings in Flanders about EMI

\begin{tabular}{|l|l|l|}
\hline Degree & Offer & Offer in English \\
\hline Undergraduate programs & 633 & $33(5.2 \%)$ \\
\hline Master's degree programs & 754 & $257(34 \%)$ \\
\hline TOTAL & 1387 & $290(21 \%)$ \\
\hline
\end{tabular}

Source: Adapted from the Higher Education Register

The numbers show that $21 \%$ of all higher education programs in Flanders have English as their medium of instruction, with 290 programs in a total offer of 1,387 for the 2019-2020 academic year. In view of undergraduate programs, 33 out of 633 (5.2\%) are in English. Concerning master's degree programs, 257 of 754, or 34\%, are taught in English. The difference in EMI adoption at the undergraduate level and master's level could be explained by the local regulations mentioned previously, that allow for a higher percentage of credits to be taught in a language other than Dutch. Furthermore, this significant difference might be explained by "a greater degree of commodification at masters' level with European institutions competing to attract non-EU fee-paying students for master's programmes in particular" (Dimova, Hultgren \& Jensen, 2015).

\section{Discussion}

An initial discussion of data related to Brazil (previously shown in this study, in section 3) indicates that, although internationalization is an incipient process in that country, as discussed by Lima and Maranhão (2009) and Miranda and Stallivieri (2017) - with important developments starting in the 2000s) - there has been a rapid increase in the number of EMI courses offered between 2016 and 2019. Portuguese is still the main language of instruction because of national regulations such as the Federal Constitution of 1988, the National Guidelines for Education (LDB) and the National Guidelines for a Common Curriculum (BNCC), discussed in the present study - in line with the view of Brazil as an apparent monolingual country (e.g. Leffa, 2013). This may explain the low 
number of international students/scholars enrolled in Brazil, since Portuguese (as a foreign language) is not as widespread as French or Spanish, for instance, making it difficult to attract such people for Brazilian HEIs. Considering the status of Portuguese in the international scenario of languages, suggestions were made to promote and strengthen this language through the Community of Portuguesespeaking Countries (CPLP, in Portuguese), ${ }^{48}$ in line with the discussions by Bagno and Carvalho (2015). However, countries like Brazil still struggle to attract international students, as mentioned by Nicolaides and Tilio (2013).

Data from Flanders ${ }^{49}$ show that such region in Belgium seems to be welcoming other languages for instruction (mainly English), in spite of explicit laws that determine the major language for instruction as being Dutch. Although being a small country (in comparison to Brazil) in geographical and demographic terms, Belgium presents a linguistic diversity which is clearly regulated by specific policies, for specific regions and communities.

With 921 EMI courses (and very few EMI full programs) being offered in Brazil (with around 8 million university students), ${ }^{50}$ and 290 full programs (21\% of its higher education offer) being offered in Flanders (with around 240,000 university students), ${ }^{51}$ there seems to be an increasing "movement" for adopting other languages of instruction (mainly English) - in line with internationalization policies such as Capes PrInt (in Brazil) and the Bologna Process (in Belgium), although Capes PrInt is focused at the postgraduate level and BP promotes mainly the undergraduate level. Considering the offer of full EMI programs and the number of students in both places, Flanders seems to be at a more advanced level of adoption of EMI, in comparison with Brazil. That is, Brazil would have to make a considerable effort to serve its 8 million (higher education) students with such courses, if Brazilian HEIs want to be in line with governmental guidelines related to education and internationalization, defined by the Ministry of Education and Capes, for instance (as previously discussed in this study).

Although most cases of EMI implementation do not follow a "one size fits all” formula (Kuteeva \& Airey, 2013), some elements are often repeated across the board. EMI issues that may arise during the implementation were described by Tsuneyoshi (2005) and Bradford (2016) in relation to linguistic, cultural, structural and institutional/identity challenges. We address these issues in the following sub-section.

\subsection{Challenges for EMI}

Linguistic challenges can occur in EMI programs (Bradford, 2016) in nonAnglophone countries and in universities located in English-speaking countries, where international students struggle to understand non-native lecturers with accented English, and struggle to understand content delivered in English, as described by Hellekjaer (2010), who discussed the comprehension of lectures in English-medium higher education. This also occurs in Brazil, for instance, as discussed in section 3, because of the low level of proficiency in English. 
Apprehensions concerning inadequate levels of English proficiency explain why students and faculty are usually tested for proficiency (Wilkinson, 2013) before starting an EMI program. In the same line, the language staff of the university may also support content lecturers in the early stages of EMI implementation, because some institutions may require lecturers to have a $\mathrm{C} 1$ level (Ball \& Lindsay, 2012), according to the CEFR as is the case in Flanders, as previously mentioned.

In general, issues related to a self-perception of inadequate proficiency in students and faculty were reported by Wächter (2008) and Huang (2015), in addition to concerns related to heterogeneity in the levels of proficiency among students (Wächter \& Maiworm, 2014), because the teaching staff has to be able to deal with this type of diversity (that is, different levels of proficiency) in the EMI classroom.

Cultural challenges are related to clashes between the characteristics of international and local participants in EMI classes. They include the style of interaction (learning and teaching styles) between teacher and students, and students interacting with each other (Bradford, 2016; Kim, Tatar \& Choi, 2014). Besides, fear of creating an English-speaking elite, to the detriment of local languages and culture were reported, for instance, in Italy (Molino \& Campagna, 2014).

Cultural concerns around EMI implementation and an apparent "superiority" of instruction in the English language usually occur in countries with prior subjugation of "minority" languages (Martinez, 2016). Discussion of data about Flanders (in Belgium), indicates that "it was not until 1930 that Dutch was recognized as the language of higher education" as "Belgium was constructed as a French-speaking state, even though French was a minority language. Its status reflected the economic and cultural power of French at that time" (van Splunder, 2010).

In Spain, ${ }^{52}$ Basque and Catalan languages also suffered subjugation. With a rapid growth of EMI in that country, there has been great discussion around its threat to local languages in Catalonia and the Basque Country (Dafouz, Camacho \& Urquia, 2014). Although evidence suggests that EMI implementation is not as negative as some people might fear (Coleman, 2006; Hu, 2009), these cultural concerns/fears should not be ignored.

Structural challenges are related to a lack of coherent EMI courses across the curricula and lack of support staff skilled enough to work with diverse participants (Bradford, 2016). Besides, recruiting and retaining faculty for EMI is not easy. Even when an institution has lecturers available to adopt EMI (and who are linguistically competent), it does not mean that such lecturers are willing to use EMI (Vinke, Snippe \& Jochems, 1998). This could be due to lack of confidence, training and financial incentives (Byun et al., 2011), or high levels of language proficiency required for lecturers (Klaassen \& Bos, 2010) and students.

EMI implementation can also create a social gap between private and public institutions. Private institutions depend less on the government and can have more control of their budgets, being able to invest more in EMI (Martinez, 2016). Therefore, research suggests that EMI adoption has a slower growth 
among public institutions (Dearden, 2014) which face several legal and budget constraints in this field.

Identity challenges are related to how the EMI program is perceived by its participants and by people outside the program, and how universities want to be seen by their partner institutions (Bradford, 2016). International research and collaboration can have an impact on the process of becoming a "world-class" 53 institution (Adams, 2013; Leta \& Chaimovich, 2002; Packer \& Meneghini, 2006), but EMI alone does not increase the reputation of the institution worldwide (Martinez, 2016) - is it sometimes only a part of ambitious plans to internationalize.

\subsection{Challenges for EMI in Brazil and in Flanders}

Brazilian HEIs face advantages and challenges for developing internationalization and offering EMI courses nationwide. On the one hand, such institutions have great advantages as Brazil has many HEIs of excellent quality, most of which are ready to offer mobility opportunities to foreign students with no enrolment or tuition fees (Freire Junior, 2016), something that is not very much common in English-speaking countries.

On the other hand, the major challenge for international students is still the obstacle with the language of instruction (e.g. Nicolaides \& Tilio, 2013), since the vast majority of courses in Brazil are taught in Portuguese, with some institutions resisting (or not seeing benefits) to offer courses in English (Nicolaides \& Tilio, 2013). Besides, Portuguese is not as widespread as other foreign languages, such as English and French, making it difficult to attract international students or hire foreign academics in Brazil. With the intention of overcoming such obstacle, Brazilian HEIs are directing financial resources and personnel to develop courses/ contents using EMI, in order to gain more visibility in the international scenario and become attractive destinations for studies.

Some European countries also resist the adoption of EMI as the choice of teaching, because languages carry symbolic national values, and have an important role in national identity (Deroey, 2013). Flanders has its own internal linguistic struggle, because the adoption of a language of instruction other than Dutch faces some resistance as Dutch "has been constructed as a key marker of Flemish identity and as a strong emancipatory force for use against the dominance of French" (van Splunder, 2014:239). That author (van Splunder, 2014) also indicates "a mismatch between the political and academic discourses on language use in Flanders" (van Splunder, 2014). Political discourse is based on a monolingual ideology, while academic discourse is based on multilingual practices and a market-driven demand for EMI.

Brazil has a history of low proficiency in foreign languages (around 5\% of Brazilians speak English, as reported previously in this study). According to the English Proficiency Index (EPI) ${ }^{54}$ developed by English First (EF), Brazil is ranked $59^{\text {th }}$ among 100 countries (mostly non-Anglophone) where the survey 
was developed. It is ranked as a "low proficiency" country. In comparison, as mentioned in section 1.2, Belgium is placed $13^{\text {th }}$ and categorized as a "very high proficiency" country (considering Flanders only, it would be placed $8^{\text {th }}$ ).

Therefore, demanding $\mathrm{C} 1$ level from faculty or students in Brazil could discourage them to take part in EMI initiatives. However, concerns about proficiency can be overcome by successful stories of lecturers using English, regardless of their level of proficiency (Rogier, 2012; Yeh, 2014) or the subject being taught (Dafouz, Camacho \& Urquia, 2014). In fact, non-native lecturers who share a first language (L1) with their students may be better understood than lecturers who are native speakers (Major et al. 2002).

Language is also a concern in Flanders, because students expect lecturers to have native-like fluency, not only showing effective communication but to speak 'correct' English. On the other hand, English is barely considered a foreign language in Flemish higher education, but a second or even first academic language (van Splunder, 2014) - something quite different from Brazil, due to local regulations from the Ministry of Education.

EMI is relatively new in Brazil and international students might face a culture shock, since the facilities and resources usually available in Brazilian public universities may differ a lot from their home institution, due to budget constraints. Besides, issues of national sovereignty also arise when EMI is adopted in a top-down fashion (Tessler, 2015), as a threat to Brazilian cultural and linguistic heritage.

In Europe, EMI adoption is a more developed phenomenon but it is unevenly spread, "being most pronounced in northern Europe, and within that Scandinavia, and least marked in southern Europe" (Ferguson, 2007). Belgium is an interesting example as it might be seen as right on the border, with its Germanic vs. Romance language division. Comparing to its neighbors in the Netherlands, one can see how its EMI offer is more substantial than it is in Flanders. For the 2019-2020 academic year there are 406 full bachelor's degree programs and 1,340 master's degree programs available in English. ${ }^{55}$

Generally speaking, lecturers may also ask for financial incentives to adopt EMI in their classes (as discussed previously), which make national goals for internationalization more likely to be successful (Ilieva, et al, 2019). They may also need pedagogical and language support from the university for EMI classes. Besides, students may also require that courses offered through EMI should be offered also in Portuguese, in the case of Brazil, since it is the official language in the country and the ones who do not speak English (because of not having access to good language education, due to financial reasons) may feel excluded from some academic activities.

As mentioned in section 3.2, Flanders has specific laws stating the allowed percentage of classes taught in languages other than Dutch. Comparing the 2003 Decree to the 2012 Decree, it became more permissive, allowing more courses to be taught in "other languages". The present offer is still below the allowed percentages but, as the tendency is for EMI growth, one can only speculate about 
the future. Will Flemish law become more tolerant? Maybe even suspending its interference and granting HEIs full control on their EMI offer? Or, will it get more restrictive in an attempt to protect Dutch and its status? These questions are yet to be addressed.

\subsection{Opportunities for EMI}

Brazil has the opportunity to learn from the experiences from other countries, since EMI is still in the early stages of implementation in Brazilian institutions (Ramos, 2018). It can also innovate in research issues and concerns that are still to be addressed in EMI implementation around the globe. With recent ongoing reforms in Education, as in the case of the National Guidelines for a Common Curriculum (BNCC, in Portuguese), policy-makers can now discuss how foreign languages (specifically, English) can be used in the curriculum and how the curriculum will be affected by the choice of languages of instruction.

Flanders has opportunities for further developing EMI at a European and a local level. Regarding the latter, the action plan for mobility, set in 2013, has recently been assessed, through the 2019 monitoring report (mentioned in section 1.1), and the figures concerning mobility are far from what was set as a goal. Aware of the current subpar state of development, Flanders will have in 2020 the opportunity to explore the results at a European level, with the end of the ET2020 framework, and to learn more from successful cases, in relation to the goals set for mobility. One likely example is the case of Netherlands, which has a higher number of EMI offer, as mentioned earlier in this study, and shares a language with Flanders.

One should notice that EMI can also help in the Internationalization at Home (IaH) initiatives (Beelen \& Jones, 2015), since it can support the integration of international and intercultural aspects into the regular curriculum of HEIs. Considering the decrease in funding for higher education and the high costs associated to academic mobility, EMI courses can profit from strategies such as COIL (Collaborative Online International Learning) to promote "virtual" mobility (Hildeblando \& Finardi, 2018) for developing language proficiency and intercultural skills. Moreover, IaH is a way to equip domestic students for a global job market (Dimova, Hultgren \& Jensen, 2015).

\section{Conclusion}

This study discussed the adoption of EMI in Brazil and Flanders (Belgium). It did so through bibliographic research and access to databases of international organizations. In line with Macaro and others (2018), there seems to be more challenges than opportunities for EMI implementation, such as the ones discussed in section 4 . With the low level of language proficiency among Brazilian students and lecturers, some actions are necessary for EMI practices to be effective in Brazil, such as partnerships and programs for developing 
proficiency, like the Languages without Borders (LwB) program, and local institutional programs developed at universities, considering the specific characteristics and needs of local academic communities. Flanders also has its own challenges for EMI adoption, because of the diverse linguistic context in Belgium and the clash between local and global values.

In the case of lecturers who do not feel ready to use EMI in their classes (due to low language proficiency, as discussed by Martinez, 2016), language experts at universities can develop courses for an initial preparation of such lecturers (and further assistance), such as the initiatives developed in the Center for Assistance in Academic Publishing (CAPA, in Portuguese $)^{56}$ at the Federal University of Parana (UFPR). CAPA offers opportunities such as the translation of articles, revision (before and after submissions), group revision and preparation for oral presentations. In the case of Flanders, writing centers such as CAPA can also have a significant impact on the implementation of EMI.

Another challenge is institutional support (e.g. Ljosland, 2015). Without such support, lecturers cannot prepare themselves for delivering contents in EMI, and students may lack linguistic preparation for EMI classes. Therefore, an institutional program may be created at the local level, in order to promote incentives (financial or not) for lecturers who can work with EMI, but do not feel compelled to do so, because they may see it as an "extra work" not worth the effort.

Cultural challenges related to fear of English hegemony (to the detriment of local languages) and to its use as a global language (Leffa, 2013) can be faced using different approaches for EMI, such as the ones described by Finardi (2014), in which English can be seen as an international language or academic lingua franca (Jenkins, Cogo \& Dewey, 2011; Jenkins, 2014), for instance.

Public institutions, which face more rigid regulations concerning public funding, may need to find other sources of financing and partners for the implementation of EMI, such as state agencies for funding research (FAPs, in the case of Brazil; and European agencies, in the case of Flanders), the Fulbright Commission and the British Council - but they should not rely exclusively on such sources/partners, which may have their own specific interests for EMI adoption. Therefore, institutions may create local forums for the discussion of alternatives for the adoption of EMI (and funding sources), since each context has its own specific needs. A follow-up unit at universities may be created to assess and verify the implementation of EMI at the local level, based on the funding sent to HEIs. In short, EMI planning, implementation and assessment represent challenges, mainly for non-Anglophone countries, which could profit from local regulations, reforms and research, so that these challenges can become opportunities.

Acknowledgements: This study was financed in part by the "Coordenação de Aperfeiçoamento de Pessoal de Nível Superior" - Brasil (CAPES) - Finance Code 001. This study was developed within the context of the Center for Studies in International Relations, at the Federal University of Espirito Santo (NERI/Ufes). 


\section{Notes}

1. Here is the size of the corpus items obtained from the bibliographic research: book chapters (18); journal articles (41); government documents (3); websites (21); reports (8); others, such as doctoral dissertations and papers presented at academic conferences (5).

2. Retrieved from: http://www.studyinflanders.be/en/education-system/the-bolo gna-process/.

3. According to Moore and Finardi (2019:275): "In much of Europe, university internationalization has, until relatively recently, been more or less equated with mobility - with the sending and receiving of personnel, especially students".

4. Available at: http://docs.vlaamsparlement.be/docs/stukken/2009-2010/g591-1bijl.pdf.

5. CAPES is the Coordination for the Development of Higher Education Personnel in Brazil, a governmental agency which provides funds for higher education in the country. More information at: https://www.capes.gov.br/.

6. $\mathrm{CNPq}$ is the National Council for Scientific and Technological Development. It is also a governmental agency which provides funds for higher education. More information at: http://www.cnpq.br/.

7. Exchange and research program established between 2011-2016, by the federal government of Brazil to promote academic mobility abroad. The main objective of this program was offering scholarships for students (mainly undergraduate) in STEM (Science, Technology, Engineering and Mathematics) areas.

8. Program initially launched in 2012 as a support for the SwB program, in order to develop language proficiency at the higher education level, by offering online courses, proficiency tests and face-to-face classes.

9. Funding program launched in 2017 by CAPES (Coordination for Development of Higher Education Personnel) to promote internationalization in the graduate level, at Brazilian universities.

10. Retrieved from: [https://en.unesco.org/sites/default/files/1-4_growth_interna tional_students.pdf], on May $11^{\text {th }}, 2019$.

11. More information at: https://www.iom.int/global-migration-trends.

12. Retrieved from: [https://data.oecd.org/students/international-student-mobility. $\mathrm{htm}]$, on May 11 $1^{\text {th }}, 2019$.

13. According to OECD, international students are those who received their prior education in another country and are not residents of their current country of study.

14. Retrieved from: [https://en.unesco.org/sites/default/files/usr_2-12_prefered_ destination_students.pdf], on May $11^{\text {th }}, 2019$.

15. According to Sousa Santos (2011), hegemonic countries are the ones where dominant/prestigious knowledge and ideologies are produced and sent to be used by "peripheral" countries, without the necessary adaptations to local contexts. This results in imbalanced relations between them, in which local and traditional knowledge are despised.

16. According to UNESCO, the outbound mobility ratio is the number of students from a given country/region enrolled in tertiary programs abroad, expressed as a percentage of total tertiary enrolment in that country/region.

17. Retrieved from: [https://en.unesco.org/sites/default/files/usr_2-10_outbound_ mobility_ratio_phds.pdf], on May $11^{\text {th }}, 2019$. 
18. More information at: https://data.oecd.org/students/international-studentmobility.htm.

19. More information at: https://www.statista.com/statistics/999553/total-numberof-students-enrolled-in-universities-in-flanders/.

20. More information at: https://eacea.ec.europa.eu/national-policies/eurydice/ content/mobility-higher-education-3_en.

21. Retrieved from: [https://ec.europa.eu/education/policies/european-policycooperation/et2020-framework_en] on November 26 ${ }^{\text {th }}, 2019$.

22. Retrieved from: [https://www.vlaanderen.be/publicaties/brains-on-the-moveactieplan-mobiliteit-2013], on November $26^{\text {th }}, 2019$.

23. Retrieved from: [https://www.onderwijs.vlaanderen.be/nl/actieplanstuden tenmobiliteit], on November $26^{\text {th }}, 2019$.

24. This number is different from the one presented in sub-section 3.2 due to differences in calculation methods. The monitoring report used the percentage of diplomas considered mobile awarded by institutions while we used the offer of EMI programs. We chose this method for section 3 since it delivers a more straightforward comparison with the data available about Brazil.

25. Outbound mobility occurs when local institutions send their students abroad to study.

26. Retrieved from: [http://data.uis.unesco.org/Index.aspx?queryid=172\#], on May $11^{\text {th }}, 2019$.

27. Incoming mobility occurs when local institutions welcome students from abroad.

28. Retrieved from: [http://www.dce.mre.gov.br/PEC/G/historico/introducao.php], on May $11^{\text {th }}, 2019$.

29. Retrieved from: [https://www.britishcouncil.org/sites/default/files/guide_brazi lian_highered_courses_inenglish_limpo_indexado_2.pdf], on May $12^{\text {th }}, 2019$.

30. STEM: Science, Technology, Engineering and Mathematics.

31. More information at: http://www.planalto.gov.br/ccivil_03/_Ato2015-2018/2017/ Lei/L13415.htm

32. Retrieved from: [http://www.planalto.gov.br/ccivil_03/_Ato2015-2018/2017/Lei/ L13415.htm] on November 27 th 2019

33. Retrieved from: [https://ec.europa.eu/eurostat/web/products-datasets/-/educ_ uoe_lang02] on November $27^{\text {th }}, 2019$.

34. Retrieved from: [https://onderwijs.vlaanderen.be/sites/default/files/atoms/ files/20190718_CLIL-scholen.xlsx] on November 27 ${ }^{\text {th }}, 2019$.

35. The number of offers is larger than the number of schools since schools might offer CLIL in more than one language.

36. Retrieved from: [https://onderwijs.vlaanderen.be/sites/default/files/atoms/files/ Masterplan-hervorming-secundair.pdf] on November 27 2019.

37. More information at: https://www.ef.com/_/ / /media/centralefcom/epi/ downloads/full-reports/v9/ef-epi-2019-english.pdf

38. More information at: https://www.ef.com/wwen/epi/regions/europe/belgium/

39. Brazilian Sign Language (LIBRAS) is acknowledged as a means of communication and expression in Law n. 10.436/2002.

40. Retrieved from: [http://portal.iphan.gov.br/pagina/detalhes/140], on May $12^{\text {th }}$, 2019. 
41. Retrieved from: [https://oglobo.globo.com/economia/emprego/brasileiros-naosabem-falar-ingles-apenas-5-dominam-idioma-6239142], on May 13 ${ }^{\text {th }}, 2019$.

42. Retrieved from: [https://www.terra.com.br/noticias/dino/95-da-populacaobrasileira-nao-fala-ingles,9f848f68ed451 de99742216570b7ccf9gc7gj8du.html] on November 27 2019.

43. More information at: https://statbel.fgov.be/en.

44. Retrieved from: [https://www.ugent.be/en/ghentuniv/organization/presentation/ history.htm], on July $1^{\text {st }} 2019$.

45. Retrieved from: [http://www.itace.be], on July $8^{\text {th }} 2019$.

46. The Higher Education Register website: https://www.highereducation.be/home

47. Retrieved from: http://www.studyinflanders.be/en/education-system/degrees/, on July $2^{\text {nd }} 2019$.

48. More information at: https://www.cplp.org/.

49. More information at: https://rm.coe.int/16802fcld7.

50. Retrieved from Census of Higher Education in 2017 - Brazilian Ministry of Education.

51. Retrieved from: https://onderwijs.vlaanderen.be/nl/hoger-onderwijs-in-cijfersschakelen-zit-in-de-lift, on July $6^{\text {th }}, 2019$.

52. For more information on Spain, please check Moore and Finardi (2019).

53. According to the authors mentioned above, a "world-class" university is an institution which constantly seeks the international recognition and visibility in the global context of higher education, even if that means the adoption of foreign models without the necessary adaptations to local contexts and needs.

54. More information available at: https://www.ef.com.br/epi/.

55. Retrieved from: www.studyfinder.nl, on July $9^{\text {th }} 2019$.

56. More information at: http://www.capa.ufpr.br/portal/

\section{References}

Adams, J. (2013). The fourth age of research (comment). Nature, 497, 557-560.

Albuquerque, C. P., Seixas, A. M., Oliveira, A. L., Ferreira, A. G., Paixão, M. P., \& Paixão, R. P. (2019). Higher Education after Bologna. Coimbra: Imprensa da Universidade de Coimbra.

Altbach, P. G., \& Knight, J. (2007). The internationalization of higher education: motivations and realities. Journal of Studies in International Education, 11(3/4), 290-305.

Araújo eSá, M. H., \& Simões, A. R. (2015). Integración curriculardela Intercomprensión: posibilidades, limitaciones, recomendaciones (Report). Brussels: European Union.

Bagno, M., \& Carvalho, O. L. de S. (2015). O potencial do português brasileiro como língua internacional. Revista Interdisciplinar, 22, 11-26.

Ball, P., \& Lindsay, D. (2012). Language demands and support for English-medium instruction in tertiary education: learning from a specific context. In A. Doiz; D. Lasagabaster; J. M. Sierra (Eds.). English-Medium Instruction at Universities: global challenges (pp. 44-61). Bristol: Multilingual Matters.

Baumvol, L. K., \& Sarmento, S. (2016). A internacionalização em casa e o uso de inglês como meio de instrução. In M. S. Beck et al. (Eds.) Echoes: further reflections on language and literature (pp. 65-82). Florianópolis, EdUFSC. 
Beelen, J., \& Jones, E. (2015). Redefining Internationalization at Home. In A. Curaj et al. (Eds.) The European Higher Education Area (pp. 59-72). Cham: Springer.

Bianchetti, L., \&Magalhães, A. M. (2015). Declaração de Bolonha einternacionalização da educação superior: protagonismo dos reitores e autonomia universitária em questão. Revista Avaliação, 20(1), 225-249.Bizon, A. C. C. (2013). Narrando o exame CELPE-BRAS e o convênio PEC-G: a construção de territorialidades em tempos de internacionalização (doctoral dissertation). Campinas: Universidade Estadual de Campinas.Bologna Declaration (1999). The Bologna Declaration of 19 June 1999. Joint declaration of the European Ministers of Education. Retrieved on May 31 $1^{\text {st }}, 2019$ from: http://www.ehea.info/cid100210/ministerial-conferencebologna-1999.html.

Bradford, A. (2016). Toward a typology of implementation challenges facing EnglishMedium Instruction in higher education: evidence from Japan. Journal of Studies in International Education, 20(4), 339-356.

Byun, K., Chu, H., Kim, M., Park, I., Kim, S., \& Jung, J. (2011). English-medium teaching in Korean higher education: policy debates and reality. Higher Education $62,431-449$.

Camargo, D. A., \& Hermany, R. (2018). Migração venezuelana e poder local em Roraima. Revista de Estudos Jurídicos UNESP, 22(35), 229-251.

Coleman, J. A. (2006). English-medium teaching in European Higher Education. Language Teaching, 39(1), 1-14.

Cucchi, C. (2019). National cultures on European corporate homepages in English: a linguistic analysis. International Journal of Business Communication, 56(2), 198232.

Da Câmara, Á. R. T. (2014). Fluxos migratórios para o Brasil no início do século XXI: respostas institucionais brasileiras (master's thesis). Universidade de Brasília.

Dafouz, E., Camacho, M., \& Urquia, E. (2014). 'Surely they can't do as well': a comparison of business students' academic performance in English-medium and Spanish-as-first-language-medium programmes. Language and Education 28(3), 223-236.

Dalton-Puffer, C. (2012). A postscript on institutional motivations, research concerns and professional implications. AILA Review, 25, 101-103.

Dearden, J. (2014). English as a medium of instruction: a growing global phenomenon. London: British Council.

Deroey, K. (2013). Relevance marking in lectures: a corpus-based study (Doctoral dissertation, Ghent University, Ghent, Belgium).

Dimova, S., Hultgren, A. K., \& Jensen, C. (2015). Introduction: English-medium instruction in European higher education: From the north to the south. In English-Medium Instruction in European Higher Education. Berlin, Germany: Walter de Gruyter GmbH \& Co KG, 1-16.

Doiz, A., Lasagabaster, D., \& Sierra, J. M. (2013). English-Medium Instruction at Universities: global challenges. Bristol, Buffalo, Toronto: Multilingual Matters.

Dowle, M. (2016). Forewords. Guide of Brazilian Higher Education Courses in English 2016. São Paulo: British Council \& FAUBAI.

European Commission (2006). Europeans and their languages (Report). Special Eurobarometer 243. Directorate General for Education and Culture. Brussels: European Commission.

Ferguson, G. (2007). The global spread of English, scientific communication and ESP: Questions of equity, access and domain loss. Ibérica, (13), 7-38. 
Finardi, K. R. (2014). The slaughter of Kachru's five sacred cows in Brazil: affordances of the use of English as an international language. Studies in English Language Teaching, 2(4), 401-411.

Finardi, K. R. (2016). Globalization and English in Brazil. In K. R. Finardi (Ed.), English in Brazil: views, policies and programs (pp. 13-32). Londrina, PR: Eduel.

Finardi, K. R. (2019). English in the South. Londrina: EDUEL.

Finardi, K., \& Archanjo, R. (2018). Washback effects of the Science without Borders, English without Borders and Languages without Borders programs in Brazilian language policies and rights. In M. Siiner et al. (Eds.), Language Policy and Language Acquisition Planning (pp. 173-186). Cham: Springer.

Finardi, K. R., \& Csillagh, V. (2016). Globalization and linguistic diversity in Switzerland: insights from the roles of national languages and English as a foreign language. In S. Grucza, M. Olpinska-Szkielko, \& P. Romanowski (Eds.), Advances in understanding multilingualism: a global perspective (pp. 59-79). Frankfurt am Main: Peter Lang.

Finardi, K. R., \& França, C. (2016). O Inglês na internacionalização da produção científica brasileira: evidências da subárea de linguagem e linguística. Revista Intersecções, 19, 234-250.

Finardi, K. R., \& Guimarães, F. F. (2017). Internacionalização, rankings e publicações em inglês: a situação do Brasil na atualidade. Estudos Em Avaliação Educacional, 28(68), 600-626.

Finardi, K. R., \& Rojo, R. A. O. (2015). Globalization, internationalization and education: what is the connection? International e-Journal of Advances in Education (IJAEDU), 1(1), 18-25.

Freire Junior, J. C. (2016). Forewords. Guide of Brazilian Higher Education Courses in English 2016. São Paulo: British Council \& FAUBAI.

Garson, K. (2016). Reframing Internationalization. Canadian Journal of Higher Education, 46(2), 19-39.

Gimenez, T., Sarmento, S., Archanjo, R., Zicman, R., and Finardi, K. (2018). Guide to English as a medium of instruction in Brazilian higher education institutions 20182019. São Paulo: British Council.

Guimarães, F. F., \& Finardi, K. R. (2018). Interculturalidade, Internacionalização e Intercompreensão: qual a relação? Revista Ilha Do Desterro, 71(3), 15-37.

Guimarães, F. F., \& Finardi, K. R. (2019). Internationalization and language policies in Brazil: evidence of the interface at UFES. Revista Organon, 34(66), 1-21.

Guimarães, F. F., Finardi, K. R., \& Casotti, J. B. C. (2019). Internationalization and language policies in Brazil: what is the relationship? Revista Brasileira de Linguística Aplicada, 19(2), 295-327.

Haus, C. (2018). Crenças de professores brasileiros de EMI sobre pronúncia. Revista $X, 13(2), 123-143$.

Hellekjaer, G. O. (2010). Lecture comprehension in English-medium higher education. Hermes - Journal of Language and Communication Studies, 45, 11-34.

Hildeblando, C. A., \& Finardi, K. R. (2018). Internationalization and virtual collaboration: insights from COIL experiences. Revista Ensino em Foco, 1(2), 19-33.

Hu, G. (2009). The craze for English-medium education in China: driving forces and looming consequences. English Today 25(4), 47-54. 
Huang, D. F. (2015). Exploring and assessing effectiveness of English medium instruction courses: the students' perspectives. Procedia - Social and Behavioral Sciences, 173, 71-78.

Ilieva, J., Killingley, P., Tsiligiris, V., \& Usher, A. (2019). The shape of global higher education: international comparisons with Europe (Report supported by the British Council).

Jenkins, J. (2014). English as a lingua franca in the international university: the politics of academic English language policy. New York: Routledge.Jenkins, J. (2015). Repositioning English and multilingualism in English as a lingua franca. Englishes in Practice, 2(3), 49-85.

Jenkins, J., Cogo, A., \& Dewey, M. (2011). Review of developments in research into English as a lingua franca. Language Teaching, 44(3), 281-315.

Jordão, C. M. (2016). Decolonizing identities: English for internationalization in a Brazilian university. Interfaces Brasil/Canadá, 16(1), 191-209.

Kim, J., Tatar, B., \& Choi, J. (2014). Emerging culture of English-medium instruction in Korea: experiences of Korean and international students. Language and Intercultural Communication 14(4), 441-459.

Klaassen, R. G., \& Bos, M. (2010). English language screening for scientific staff at Delft University of Technology. Hermes - Journal of Language and Communication Studies, 45, 61-75.

Knight, J. (2003). Updating the definition of internationalization. International Higher Education, 33, 2-3.

Knobel, M. (2012). Brazil seeks academic boost by sending students abroad. International Higher Education, 66, 15-17.

Kubota, R. (2009). Internationalization of universities: paradoxes and responsibilities. The Modern Language Journal, 93(4), 612-616.

Kumaravadivelu, B. (2003). A postmethod perspective on English language teaching. World Englishes, 22(4), 539-550.

Kuteeva, M., \& Airey, J. (2013). Disciplinary differences in the use of English in higher education: reflections on recent language policy developments. Higher Education, 67(5), 533-549.

Lanvers, U., \& Hultgren, A. K. (2018). The Englishization of European education: foreword. European Journal of Language Policy, 10(1), 1-11.

Law Concerning Language Regulation in Education. (1963). Wet houdende taalregeling in het onderwijs. http://www.ond.vlaanderen.be/edulex/data-base/ document/document.asp? docid $=12391$

Leask, B. (2015). Internationalizing the Curriculum. New York: Routledge.

Leffa, V. J. (2013). Prefácio. In C. Nicolaides et al. (Eds.), Política e Políticas Linguísticas (pp. 7-10). Campinas, SP: Pontes Editores.

Leta, J., \& Chaimovic, H. (2002). Recognition and international collaboration: the Brazilian case. Scientometrics, 53(3), 325-335.

Lima, M. C., \& Maranhão, C. M. S. A. (2009). O sistema de educação superior mundial entre a internacionalização ativa e passiva. Revista Avaliação, 14(3), 583-610.

Lin, H. Y. (2019). Perceptions of the Englishization of higher education in Taiwan: implementation and implications. International Journal of Bilingual Education and Bilingualism. DOI: 10.1080/13670050.2019.1579778. 
Lindström, J. (2012). Different languages, one mission? Outcomes of language policies in a multilingual university context. International Journal of the Sociology of Language, (216), 33-54.

Liu, X. (2019). National policies and the role of English in Higher Education. International Higher Education, 96, 15-16.

Ljosland, R. (2015). Policymaking as a multi-layered activity. A case study from the higher education sector in Norway. Higher Education, 70(4), 611-627.

Macaro, E. (2015). English Medium Instruction: time to start asking some difficult questions. Modern English Teacher, 24(2), 4-7.

Macaro, E., Curle, S., Pun, J., An, J., \& Dearden, J. (2018). A systematic review of English medium instruction in higher education. Language Teaching 51(1), 36-76.

Machado, K. G. W. (2019). Os MOOCs como possibilidade para internacionalização da educação superior em casa (master's thesis). Pontifícia Universidade Católica do Rio Grande do Sul, Porto Alegre.

Major, R. C., Fitzmaurice, S. F., Bunta, F., \& Balasubramanian, C. (2002). The effects of nonnative accents on listening comprehension: implications for ESL assessment. TESOL Quarterly, 36(2), 173-190.

Manços, G. R., \& Coelho, F. S. (2017). Internacionalização da ciência brasileira: subsídios para avaliação do programa Ciência sem Fronteiras. Revista Brasileira de Políticas Públicas e Internacionais, 2(2), 52-82.

Martinez, R. (2016). English as a Medium of Instruction (EMI) in Brazilian higher education: challenges and opportunities. In K. R. Finardi (Ed.), English in Brazil: views, policies and programs (pp. 191-228). Londrina, PR: EDUEL.

Martins, S. A. (2014). A intercompreensão de línguas românicas: proposta propulsora de uma educação plurilíngue. Revista Moara, 42, 117-126.

Meissner, F.-J. (2010). La didáctica de la Intercomprensión y sus repercusiones en la enseñanza de lenguas: el ejemplo alemán. Synergies Chili, 6, 59-70.

Miranda, J. A. A., \& Stallivieri, L. (2017). Para uma política pública de internacionalização para o ensino superior no Brasil. Revista Avaliação, 22(3), 589-613.

Molino, A., \& Campagna, S. (2014). English-mediated instruction in Italian universities: conflicting views. In U. Ammon, J. Darquennes \& S. Wright (Eds.), Sociolinguistica: International Yearbook of European Sociolinguistics (pp. 155-171). Berlin: Walter de Gruyter GmbH.

Moore, P., \& Finardi, K. R. (2019). The role of English and internationalization in the South... of the North. In K. R. Finardi (Ed.), English in the South (pp. 267-293). Londrina, PR: Eduel.

Nicolaides, C. S., \& Tilio, R. C. (2013). Políticas de ensino e aprendizagem de línguas adicionais no contexto brasileiro: o caminho trilhado pela ALAB. In C. Nicolaides et al. (Eds.), Política e Políticas Linguísticas (pp. 285-305). Campinas, SP: Pontes Editores.

Packer, A. L., \& Menghini, R. (2006). Articles with authors affiliated to Brazilian institutions published from 1994 to 2003 with 100 or more citations: I - the weight of international collaboration and the role of networks. Anais da Academia Brasileira de Ciências, 78(4), 841-853.

Ramos, M. Y. (2018). Internacionalização da pós-graduação no Brasil: lógica e mecanismos. Revista Educação e Pesquisa, 44, 1-22. 
Relaño-Pastor, A. M. (2015). The commodification of English in "Madrid, comunidad bilingüe": insights from the CLIL classroom. Language Policy, 14, 131-152.

Rogier, D. (2012). The effects of English-medium instruction on language proficiency of students enrolled in higher education in the UAE (Doctoral dissertation). University of Exeter, UK.

Schmidt-Unterberger, B. (2018) The English-medium paradigm: a conceptualisation of English-medium teaching in higher education, International Journal of Bilingual Education and Bilingualism, 21(5), 527-539.

Sin, C., Veiga, A., \& Amaral, A. (2016). European Policy Implementation and Higher Education: Analysing the Bologna Process. Basingstoke, England: Springer.

Sousa Santos, B. (2011). Epistomologías del Sur. Utopía y Praxis Latinoamericana, 16(54), 17-39.

Spolsky, B. (2004). Language Policy. New York: Cambridge University Press.

Taquini, R., Finardi, K. R., \& Amorim, G. B. (2017). English as a Medium of Instruction at Turkish state universities. Education and Linguistics Research, 3(2), $35-53$.

Tessler, L. R. (2015). Teaching in English at the undergraduate level in a Brazilian public university. Paper presented at FAUBAI Conference 2015. Cuiabá-MS, Brazil.

Tsuneyoshi, R. (2005). Internationalization strategies in Japan: the dilemmas and possibilities of study abroad programs using English. Journal of Research in International Education, 4(1), 65-86.

van Splunder, F. (2010). English as a medium of instruction in Flemish higher education: Language and identity management in a Dutch-speaking context (Doctoral dissertation, Lancaster University, Lancaster, England).

van Splunder, F. (2014). Negotiating multilingualism in Flemish higher education. In J. W. Unger, M. Krzyżanowski, \& R. Wodak (Eds.), Multilingual encounters in Europe's institutional spaces (pp. 221-242). London: Bloomsbury.

Verdu, F. C. (2017). EMI (English as a Medium of Instruction) como estratégia de Internacionalização em Casa: um estudo de caso num programa de pós-graduação em administração. In Encontro da ANPAD (EnANPAD) 2017. São Paulo, October 2017.

Vertovec, S. (2007). Super-diversity and its implications. Ethnic and Racial Studies, 30(6), 1024-1054.

Vinke, A. A., Snippe, J., \& Jochems, W. (1998). English-medium content courses in non-English higher education: a study of lecturer experiences and teaching behaviors. Teaching in Higher Education 3(3), 383-394.

Wächter, B. (2008). Teaching in English on the rise in European education. International Higher Education, 52, 3-4.

Wächter, B., \& Maiworm, F. (2014). English-taught programmes in European higher education: the state of play in 2014. Bonn: Lemmens Medien GmbH.

Wang, X., Spotti, M., Juffermans, K., Cornips, L., Kroon, S., \& Blommaert, J. (2014). Globalization in the margins: toward a re-evaluation of language and mobility. Applied Linguistics Review, 5(1), 23-44.

Wilkinson, R. (2013). English-Medium Instruction at a Dutch university: challenges and pitfalls. In A. Doiz, D. Lasagabaster, \& J. M. Sierra (Eds.) English-Medium Instruction at Universities: global challenges (pp. 3-24). Bristol, Buffalo, Toronto: Multilingual Matters. 
Yeh, C. C. (2014). Taiwanese students' experiences and attitudes towards Englishmedium courses in tertiary education. RELC Journal, 45(3), 305-319.

Recebido em: 22/07/2019

Aceito em: 22/11/2019 